\title{
Interrelationships of forage and steer growth dynamics on wheat pasture
}

\author{
W.E. PINCHAK, W.D. WORRALL, S.P. CALDWELL, L.J. HUNT, N.J. WORRALL, AND \\ M. CONOLY
}

Authors are with the Texas Agricultural Experiment Station, Chillicothe-Vernon Research and Extension Center, Vernon, Tex. 76385.

\begin{abstract}
Little information is available comparing animal performance or stocking stability for different wheat (Triticum aestivum L.) cultivars. Wheat is annually planted on 10 million ha in the Southern Great Plains. Our objective was to determine the effects of wheat cultivars with different forage production potentials on the seasonal and total productivity of steers. 'Lancota' and 'NK Pro 812' (NK 812) were planted in September 1987 and October 1988 at the W.T. Waggoner Ranch in north Texas. Hereford steers (Bos taurus L.), 220 to $233 \mathrm{~kg}$. were grazed from November 1987 to May 1988 and December 1988 to April 1989. Seasonal and total forage production and disappearance were affected $(p<0.05)$ by season and year. Cultivar did not affect forage production and disappearance. Steer average daily gain (ADG), gain head ${ }^{-1}$, and gain $\mathrm{ha}^{-1}$ were significantly affected by year, season, year $\times$ season, and cultivar $\times$ season interactions. Steer gain ha ${ }^{-1}$ was lower $(P<0.10)$ in year 2 than year 1 for both cultivars. Both gain head ${ }^{-1}$ and gain $\mathrm{ha}^{-1}$ were lower $(\mathrm{P}<0.10)$ on NK 812 than Lancota in year 2. Season long gain ha-1 followed similar trends to gain $^{\text {head }}{ }^{-1}$. A season $\times$ year interaction $(P<0.05)$ occurred because NK 812 matured earlier and was less winter hardy than Lancota. Across years steer ADG increased

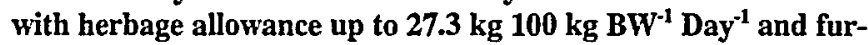
ther increases in herbage allowance had limited effect on steer ADG. Yearly variation in environmental conditions had greater effects on steer performance and forage production than cultivar.
\end{abstract}

Key Words: Average Daily Gain, stocking stability, small grain pastures, herbage allowance

In the Southern Great Plains, winter wheat (Triticum aestivum L.) is annualy sown on about 10 million ha (Christiansen et al. 1989). Annual changes in the government farm program, market, and environmental conditions determine the proportion of wheat acreage managed for grain production, combined cattle grazing

This manuscript is published with approval of the Director, Texas Agricultural Experiment Station as TA-31827. This research was supported by the Expanded Research Program of TAES and the E. Paul and Helen Buck Waggoner Foundation. We sincerely appreciate the W.T. Waggoner Estate for providing the land, farming, cattle and labor for this project. We gratefully acknowledge the field assistance of R. Scott, R. Cochran and S. Dowhower. The manuscript was typed by M.S. Stone and graphics were prepared by K.J. Young. and grain production, and cattle grazing only (graze-out) (Harman et al. 1984). In a given year, 30 to $80 \%$ of the wheat acreage in the Southern Great Plains is grazed at some time while 10 to $20 \%$ is grazed out. Profitability of wheat production systems in the region depends on income derived from both cattle and grain production.

Wheat cultivar development has been directed toward grain production (Carver et al. 1991, Winter and Thompson 1990), while wheat pasture grazing research has focused on the impacts of intensity and timing of defoliation on subsequent grain yields (Winter and Thompson 1987, 1990, Winter and Musick 1991, Christiansen et al. 1989, Dunphy et al. 1984). Forage production characteristics of wheat cultivars (Worrall and Gilmore 1985, Carver et al. 1991) have been examined with clipping treatments imposed at a predetermined season or regrowth interval.

Beef cattle research on wheat pasture has focused on bloat problems (Bartley et al 1975, Horn and Frost 1982) and the evaluation supplementation and management strategies (Horn et al. 1981, Mader et al. 1983, Mader and Horn 1986, Anderson and Horn 1987). Supplementation strategies to increase stocking density have also been evaluated by Cravey et al. 1993 and Horn et al. 1995. Conspicuously absent are effects of wheat cultivar selection on stocking stability, seasonal patterns of animal performance, and forage production.

Our objectives were to characterize and elucidate the relationships between forage growth dynamics and stocker steer performance under graze-out management for 2 wheat cultivars differing in forage production potential (Worrall and Gilmore 1985).

\section{Materials and Methods}

The study area was located in western Wilbarger County. Texas ( $33^{\circ} 57^{\prime} \mathrm{N}, 99^{\circ} 26^{\prime} \mathrm{W}$ ). Annual precipitation averages 584 $\mathrm{mm}$ and is bimodally distributed in spring and fall (Fig. 1). Average maximum daily temperatures range from $36^{\circ} \mathrm{C}$ in July to $11^{\circ} \mathrm{C}$ in January.

Soils on the study area were an Abilene clay loam (fine, mixed, thermic Pachic Paleustiolls). A 152-ha field was subdivided with two-strand electric fence into four 38-ha pastures. Pastures were fertilized with $45 \mathrm{~kg} \mathrm{~N} \mathrm{ha}^{-1}$ in August and planted in midSeptember at $67 \mathrm{~kg}$ wheat seed ha'. 'Lancota' and 'NK Pro Brand 812' (NK 812) wheat cultivars were selected based on 
long-term clipping data (Worrall and Gilmore 1985), which indicated Lancota is a late maturing, standard height cultivar that produces 1,070 to $1,780 \mathrm{~kg} \mathrm{ha}^{-1}$ more forage than NK 812 , an earlier maturing, semi-dwarf cultivar. Pastures were sown to the same variety in both 1987 and 1988 to reduce stand contamination by volunteer plants. In 1988 , seed were sown in dry soil and surface soil crusted after $152 \mathrm{~mm}$ rain in September. Seed germinated but failed to emerge and pastures were reseeded on 4 and 5 October.

Each year, 160 non-implanted, Hereford steers (Bos taurus L.) were stratified by weight into 4 groups of 40 head. Steers were from the same dam and sire groups in both years. Steers were preconditioned for 30 to 79 days. Steers were given free choice forage sorghum hay and $0.5 \mathrm{~kg} \mathrm{hd}^{-1}$ day $^{-1}$ of a $32 \%$ crude protein supplement during the preconditioning phase. Initial steer weights averaged 220 and $233 \mathrm{~kg}$ in 1987 and 1988, respectively. Steers were individually weighed at approximately 28 -day intervals. Cattle were weighed at mid-day and without a shrink. In 1988 , initial weights were $13 \mathrm{~kg}$ heavier because the preconditioning period was 34 days longer than in 1987. Across both years the incidence of sickness on pasture was less than $2 \%$. Grazing commenced on 10 November 1987 and 14 December 1988. A variable stocking rate method was used to evaluate cultivars. Initial stocking rate in all pastures was 0.95 ha steer ${ }^{-1}$ in both years based on historical stocking rates in the region. In 1987-88, stocking rate was increased to 0.59 ha steer ${ }^{-1}$ in March at jointing (Feekes Stage 6 ) by adding 25 steers to each pastures. In 1988-89, no additional steers were used. Grazing in the NK 812 pastures was terminated on 30 March 1989 when forage biomass fell below $267 \mathrm{~kg} \mathrm{ha}^{-1}$ as a result of freeze damage. Steers from NK 812 treatments were moved to Lancota pastures increasing stocking rate to 0.48 ha steer ${ }^{-1}$ until 13 April 1989. Grazing was terminated on 2 May 1988 and 13 April 1989.

At 14- to 35-day intervals, wheat standing crop, growth, and disappearance were estimated clipping wheat herbage in 20 paired caged and grazed plots $(1 \times 1-\mathrm{m})$ pasture ${ }^{-1}$. Forage growth, disappearance, and total forage production were calculated via positive peak summation of forage biomass (Defosse and Bertiller 1991). Herbage allowance was calculated as the $\mathrm{kg}$ forage dry matter $100 \mathrm{~kg}$ steer body weight ${ }^{-1}$ day $^{-1}$ in each pasture on each sample date in both grazing years. We eliminated 4 sampling dates from average daily gain (ADG) and herbage allowance analyses because of snow, ice cover, extreme cold (10 December 1987 and 26 January 1989) and compensatory gain (10 and 24 November 1987).

Data were analyzed using repeated measures analysis of vari- ance (SAS 1987). Seasonal analyses of forage production and disappearance and animal performance were based on pooling sample dates into early (November through mid-January), mid (mid-January to mid-March) and late (mid-March through grazeout) seasons. Whole plot was year tested by the replicate within year interaction. The sub-plot was comprised of cultivar and the cultivar $x$ year interaction and was tested by the cultivar $x$ replicate within year interaction. The sub-sub-plot consisted of season, season $\times$ year, season $\times$ cultivar, and season $\times$ year $\times$ cultivar and was tested by season $x$ cultivar $\times$ replicate within year. Mean separations were based on a protected Student-Newman-Keuls (SNK) test (Zar 1974). Nonlinear regression plateau analyses (SAS 1987) were used to examine the relationships between herbage allowance and average daily gain (ADG).

\section{Results and Discussions}

\section{Forage and Animal Production Dynamics}

Forage production and disappearance varied between years and seasons $(\mathrm{P}<0.05)$ (Table 1). Total forage production of Lancota and 812 did not differ within or among years. Total forage production was greater $(\mathrm{P}<0.05)$ in 1987-88 than 1988-89.

A significant $(\mathrm{P}<0.01)$ year $\times$ season interaction in forage biomass production resulted from late season declines in production in 1988-89 compared to increases in late season production in 1987-88 (Table 1). Across years and cultivars, forage biomass production exceeded forage disappearance in early- and late-seasons, however, disappearance exceeded production in mid-season. In $1988-89$, forage disappearance was equal to or greater than forage growth, reflecting the adverse effects of freeze damage and drought (Fig. 1) on late-season forage growth.

Yearly variation in precipitation and temperature had more impact on individual animal performance and gain per ha and forage biomass than wheat cultivar. This agrees with Carver et al. (1991) relative to differences in seasonal forage production and regrowth of different wheat cultivars. West et al. (1991) also reported that growing degree days were correlated with yearly patterns of phenological development, forage yield, and forage quality of small grains.

Degree of winter hardiness and maturation rate apparently affected seasonal and total stocker cattle production more than estimated forage production potential based on clipping. These results are not surprising because there has been little selection for seasonal or total forage production in wheat breeding pro-

Table 1. Effect of year $\times$ season interaction on forage production and disappearance of two wheat cultivars under grazing in the North Texas Rolling Plains.

\begin{tabular}{|c|c|c|c|c|c|c|c|c|c|c|c|c|c|c|c|c|}
\hline \multirow[b]{3}{*}{ Parameter } & \multicolumn{14}{|c|}{ Year } & & \\
\hline & \multicolumn{7}{|c|}{$\begin{array}{c}1987-1988 \\
\text { Season }\end{array}$} & \multicolumn{9}{|c|}{$\begin{array}{c}1988-1989 \\
\text { Season }\end{array}$} \\
\hline & Early & SEM & Mid & SEM & Late & SEM & Total & SEM & Early & SEM & Mid & SEM & Late & SEM & Total & SEM \\
\hline & $=-\ldots$ & $\cdots$ & - - & $\cdots$ & $\ldots . .$. & $\ldots$ & - - - & $(\mathrm{Kg}$ & $\cdots$ & - & -8 & -8 & $-\cdots$ & $-\ldots$ & - - & $\cdots$ \\
\hline $\begin{array}{l}\text { Forage } \\
\text { production }\end{array}$ & $2008 b^{b}$ & 183 & $1073 \mathrm{c}$ & 44 & $3502 a$ & 157 & $6577 x^{2}$ & 441 & $1394 a$ & 35 & $1149 \mathrm{ab}$ & 190 & $729 \mathrm{~b}$ & 264 & $2962 y$ & 180 \\
\hline $\begin{array}{l}\text { Forage } \\
\text { disappearance }\end{array}$ & $423 c$ & 71 & $1309 b$ & 107 & $2753 a$ & 183 & $4545 x$ & 298 & $410 \mathrm{~b}$ & 45 & $1157 \mathrm{a}$ & 115 & $894 a$ & 162 & $2462 y$ & 287 \\
\hline
\end{tabular}

$1_{\mathrm{a}, \mathrm{b}, \mathrm{c}}$ Means within a row and year without the same letter differ at $\mathrm{P}<0.05$.

${ }^{2} x, y$ Total means within a parameter without the same letter differ at $P<0.05$. 


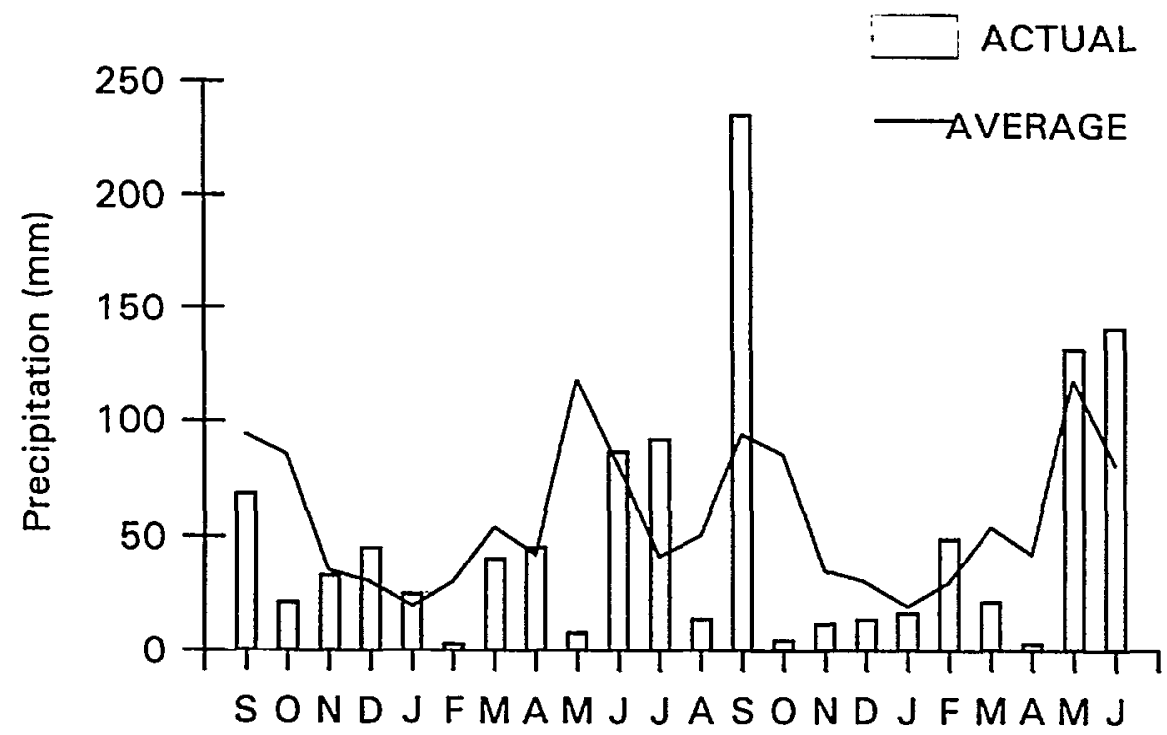

MONTHS

1987

1988

1989

Fig. 1. Monthly mean and actual precipitation over the course of the study period. Line is 20 year mean precipitation at Vernon, Tex. Bars are actual monthly total precipitation at Vernon, Tex.

grams. Carver et al. (1991) concluded there was sufficient available wheat germplasm to select for seasonal and total forage production as an attribute in future cultivar development.

Observed estimates of forage biomass production are greater than those commonly reported for the Southern Great Plains (Worrall and Gilmore 1985, Carver et al. 1991). Two probable reasons can explain these discrepancies. First, previous research utilized mechanical harvest techniques or hand clipping to $2 \mathrm{~cm}$ heights, whereas we hand harvested to ground level. Second, peak summation of positive estimates of standing crop has been found to over estimate above-ground net primary production in heterogeneous plant communities (Biondini et al. 1991). We believe that over estimation would be less in annual small grain monocultures than reported by Biodini et al. (1991).
Animal average daily gain (ADG), gain $\cdot h^{-1}$ and gain $\cdot \mathrm{ha}^{-1}$ varied as a complex function of year, season, cultivar, season $x$ year, and season $x$ cultivar interactions (Table 2). Year and associated year interactions were primarily the result of delayed planting in the fall 1988 , lower precipitation, and low temperatures $\left(-13^{\circ} \mathrm{C}\right)$ in February 1989 (Fig. 1). The impact was a 60-day reduction in length of the 1989 grazing season.

Average daily gain increased throughout the 1987-88 grazing season (Table 3). During early- and mid-season average daily gain (ADG) gain $\mathrm{hd}^{-1}$, and gain ha ${ }^{-1}$ were generally greater than during early- and mid-season. Late season increases in steer performance were associated with rapid growth of wheat at jointing (Feekes Stage 6) Early-season 1987-88 and mid-season 1988-89 ADG and gain ha ${ }^{-1}$ from NK 812 tended $(\mathrm{P}<0.15)$ to be greater

Table 2. Repeated measures analysis of variance for the effects of year, cultivar, season, and associated interactions on performance of steers grazing different wheat varieties.

\begin{tabular}{|c|c|c|c|c|c|c|c|}
\hline \multicolumn{2}{|l|}{ Parameter } & \multicolumn{2}{|c|}{$\mathrm{ADG}^{1}$} & \multicolumn{2}{|c|}{ GPHA $^{2}$} & \multicolumn{2}{|c|}{ GPHD $^{3}$} \\
\hline Effect & df & F & $\mathrm{p}<\mathrm{F}$ & $\mathrm{F}$ & $\mathrm{p}<\mathrm{F}$ & $\mathrm{F}$ & $\mathrm{p}<\mathrm{F}$ \\
\hline$\overline{\text { Year [Y] }}$ & 1 & 9.13 & 0.094 & 965.43 & 0.001 & 155.24 & 0.006 \\
\hline $\operatorname{Rep}(Y)$ & $2-$ & $\ldots$ & $\ldots$ & 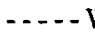 & $r=\ldots$ & 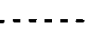 & $\ldots$ \\
\hline Cultivar [C] & 1 & 96.58 & 0.010 & 3.47 & 0.204 & 14.44 & 0.063 \\
\hline $\mathrm{CxY}$ & 1 & 53.97 & 0.018 & 0.09 & 0.790 & 1.54 & 0.341 \\
\hline CxRep(Y) & $2-$ & $\ldots$ & $\ldots$ & $\ldots$ & $\ldots .$. & $\ldots$ & . . . . . \\
\hline Season [S] & 2 & 6.75 & 0.019 & 56.35 & $<0.001$ & 84.94 & $<0.001$ \\
\hline SXY & 2 & 10.53 & 0.006 & 121.14 & $<0.001$ & 153.91 & $<0.001$ \\
\hline $\mathrm{SxC}$ & 2 & 9.53 & 0.008 & 10.57 & 0.006 & 16.61 & 0.001 \\
\hline SxYXC & 2 & 3.07 & 0.103 & 0.55 & 0.599 & 2.43 & 0.150 \\
\hline $\operatorname{SxCxRep(Y)}$ & 8- & $\ldots$ & - & $-\ldots-S t$ & or- - . - & -1 & $\ldots$ \\
\hline
\end{tabular}

${ }^{\mathrm{ADG}}=$ Average daily gain $\left(\mathrm{kg} \cdot \mathrm{hd}^{-1} \cdot \mathrm{d}^{-1}\right)$

${ }^{2} \mathrm{GPHA}=\mathrm{Gainh} \mathrm{ha}^{-1}\left(\mathrm{~kg} \cdot \mathrm{ha}^{-1}\right)$

${ }^{3} \mathrm{GPHD}=$ Gain $h d^{-1}\left(\mathrm{~kg} \cdot \mathrm{hd}^{1}\right)$ 
Table 3. Effects of wheat cultivar, season, and year on steer average daily gains, gain head', and gain ha' ${ }^{-1}$ under grazeout management.

\begin{tabular}{|c|c|c|c|c|c|c|c|c|c|c|c|c|c|}
\hline \multirow[b]{3}{*}{ Parameter } & \multicolumn{13}{|c|}{ Year } \\
\hline & \multirow[b]{2}{*}{ Cultivar } & \multicolumn{5}{|c|}{$\begin{array}{c}1987-88^{1} \\
\text { Season }\end{array}$} & \multicolumn{7}{|c|}{$\begin{array}{r}1988-89 \\
\text { Season }\end{array}$} \\
\hline & & $\begin{array}{l}\text { Early } \\
\text { (53d) }\end{array}$ & SEM & $\begin{array}{l}\text { Mid } \\
\text { (55d) }\end{array}$ & SEM & $\begin{array}{l}\text { Late } \\
\text { (62d) }\end{array}$ & SEM & $\begin{array}{l}\text { Early } \\
\text { (31d) }\end{array}$ & SEM & $\begin{array}{l}\text { Mid } \\
(65 d)\end{array}$ & SEM & $\begin{array}{l}\text { Late } \\
\text { (13 to } \\
\text { to } 22 d \text { ) }\end{array}$ & SEM \\
\hline Average Daily Gain & Lancota & $0.62 b^{1}$ & 0.03 & $0.86 \mathrm{~b}$ & 0.11 & $1.19 \mathrm{ax}^{2}$ & 0.03 & $0.62 \mathrm{~b}$ & 0.08 & $0.97 \mathrm{a}$ & 0 & $1.00 \mathrm{ax}$ & 0.03 \\
\hline$\left(k g h d^{-1} d^{4}\right)$ & NK Pro 812 & $0.68 b$ & 0.01 & $0.86 a$ & 0.06 & 1.00 ay & 0.05 & $0.70 \mathrm{~b}$ & 0.04 & $1.07 \mathrm{a}$ & 0.21 & $0.19 c y$ & 0.12 \\
\hline$\left(\mathrm{kg} \mathrm{hd}^{-1}\right)$ & NK Pro 812 & $4 \mathrm{Ib}$ & $<1$ & $48 \mathrm{~b}$ & 3 & 62ay & 3 & $21 b$ & 2 & 70ay & 2 & $3 c y$ & 2 \\
\hline Gain per hectare & Lancota & $40 \mathrm{~b}$ & 2 & $44 b$ & 7 & $141 a x$ & 5 & $18 \mathrm{c}$ & 3 & $58 a x$ & 0 & $34 \mathrm{bx}$ & 1 \\
\hline$\left(\mathrm{kg} \mathrm{ha}^{-1}\right)$ & NK Pro 812 & $45 \mathrm{~b}$ & $<1$ & $45 \mathrm{~b}$ & 4 & 116ay & 16 & $20 \mathrm{~b}$ & 5 & $65 a y$ & 2 & $3 c y$ & 2 \\
\hline
\end{tabular}

$a, b, c$ Means within a year and row not having the same letter differ at $P<0.10$.

${ }^{2} x, y$ Means within a parameter and season not having the same letter differ at $P<0.10$.

than from Lancota. Early- to mid-season increases in animal performance from NK 812 may be attributed to a more erect growth habit than Lancota, which improves ease of harvest. Late-season performance was greater on Lancota than NK 812, because NK 812 matures earlier than Lancota.

Table 4. Year $X$ cultivar interaction effects on steers season-long under grazeout management of wheat pasture'.

\begin{tabular}{|c|c|c|c|c|c|}
\hline Parameter & Cultivar & $\frac{\text { Year }}{1987-88}$ & SEM & $\frac{\text { Year }}{1988-89}$ & SEM \\
\hline $\begin{array}{l}\text { Average Daily } \\
\text { Gain (kg) }\end{array}$ & $\begin{array}{l}\text { Lancota } \\
\text { NK } 812\end{array}$ & $\begin{array}{l}0.89 \\
0.85\end{array}$ & $\begin{array}{l}0.1 \\
0.06\end{array}$ & $\begin{array}{l}0.89 \\
0.86\end{array}$ & $\begin{array}{l}0.08 \\
0.15\end{array}$ \\
\hline $\begin{array}{l}\text { Gain hd } \\
(\mathrm{kg})\end{array}$ & $\begin{array}{l}\text { Lancota } \\
\text { NK } 812\end{array}$ & $\begin{array}{l}158 a^{2} \\
151 a\end{array}$ & $\begin{array}{l}7 \\
4\end{array}$ & $\begin{array}{r}108 \mathrm{~b} \\
94 \mathrm{~b}\end{array}$ & $\begin{array}{r}9 \\
12\end{array}$ \\
\hline $\begin{array}{l}\text { Gain ha }{ }^{-1} \\
(\mathrm{~kg})\end{array}$ & $\begin{array}{l}\text { Lancota } \\
\text { NK } 812\end{array}$ & $\begin{array}{l}229 a \\
208 a\end{array}$ & $\begin{array}{r}19 \\
5\end{array}$ & $\begin{array}{c}125 b x^{3} \\
99 b\end{array}$ & $\begin{array}{r}8 \\
13\end{array}$ \\
\hline
\end{tabular}

In 1988-89, grazing of NK 812 pastures was terminated 14 days before Lancota pastures and NK 812 steers were added to Lancota pastures. Gain of NK 812 steers was added to Lancota steers for calculations of gain per hectare.

${ }^{2} \mathrm{a}, \mathrm{b}$ Means within a parameter and cultivar not having a common letter differ at $P<0.10$.

${ }^{3} \mathrm{x}, \mathrm{y}$ Means within a parameter and year not having a common letter differ at $P<0.10$

Grazing in 1988 commenced on 14 December, 22 days later than in 1987. Consequently, early-season gain $\mathrm{hd}^{-1}$ and gain ha ${ }^{-1}$ in 1988 were lower for both cultivars than in 1987 (Table 3). A cultivar $\times$ season interaction $(p<0.01)$ was noted for average daily gain (ADG) in 1988-89. The ADG of Lancota steers remained the same from mid to late season $\left(1 \mathrm{~kg} \mathrm{hd}^{-1}\right.$ day $\left.^{-1}\right)$ while ADG of NK 812 steers decreased $\left(0.19 \mathrm{~kg} \mathrm{hd}^{-1}\right.$ day $\left.^{-1}\right)$ after a freeze damaged NK 812. Late winter drought (Fig. 1) and freeze damage in
1989 combined to reduce the late grazing season to only 13 days and 22 days for NK 812 and Lancota treatments, respectively. Corresponding decreases in gain hd $\mathrm{hd}^{-1}$ and gain ha $\mathrm{h}^{-1}$ occurred in both cultivars. In both years late-season gain hd ${ }^{-1}$ and gain ha ${ }^{-1}$ on Lancota pastures was greater than on NK 812 pastures. In 1987-88, gain hd ${ }^{-1}$ and gain ha ${ }^{-1}$ peaked during late-season grazing, but in 1988-1989, peak performance and gain occurred during mid-season grazing.

Season-long average daily gain (ADG) based on days actually grazed, was similar for Lancota and NK 812 in both years (Table 4). In contrast, gain hd ${ }^{-1}$ was less in 1988-89 than 1987-88 (Lancota decreased by $32 \%$ and NK 812 decreased by $38 \%$ ). Similarly, gain ha ${ }^{-1}$ in $1988-89$ decreased $45 \%$ and $52 \%$ for Lancota and NK 812, respectively. Season-long gain ha ${ }^{-1}$ was greater (Table 4) on Lancota than on NK 812 pastures reflecting the shortened grazing season for 812 .

\section{Herbage Allowance and Animal Performance}

Herbage allowance across years and cultivars ranged from 4.4

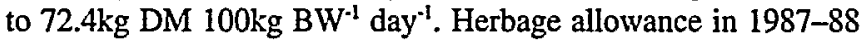
ranged from 8.1 to $72.4 \mathrm{~kg} \mathrm{DM} 100 \mathrm{~kg} \mathrm{BW}^{-1} \mathrm{day}^{-1}$. In 1988-89 herbage allowance ranged from 4.4 to $65.6 \mathrm{~kg} \mathrm{DM}^{100 \mathrm{~kg} \mathrm{BW}^{-1}}$ Day $^{-1}$. Combined across years steer averaged daily grain (ADG) responded in a quadratic manner up to a critical value of $27.3 \mathrm{~kg}$ DM $100 \mathrm{~kg} \mathrm{BW}^{-1}$ day ${ }^{-1}$ and plateaued at ADG's of $1.21 \mathrm{~kg}$ (Table 5). Separate analyses by year indicated that the intercepts and slopes differed between years (Table 5). In 1987-88 the critical value of herbage allowance was $40.1 \mathrm{~kg}$ DM $100 \mathrm{~kg} \mathrm{BW}^{-1}$ day $^{-1}$ and $19 \mathrm{~kg} \mathrm{DM} 100 \mathrm{~kg} \mathrm{BW}^{-1}$ day $^{-1}$ in 1988-89. Wheat growth conditions were markedly different between years. Precipitation was

Table 5. Relationship of steer average daily gain $(\mathrm{kg})$ to herbage allowance $\left(\mathrm{Kg} \mathrm{DM} 100 \mathrm{~kg} \mathrm{BW}^{-1}\right.$ day $\left.{ }^{-1}\right)$ of wheat across and within years.

\begin{tabular}{lcccccccc}
\hline \hline Year & $\mathrm{n}$ & $\mathrm{r}^{2}$ & MSE & $\mathrm{b}_{\mathrm{o}}{ }^{1}$ & $\mathrm{~b}_{1}$ & $\mathrm{~b}_{2}$ & \multicolumn{2}{c}{ Critical Value $^{2}$ Plateau $^{3}$} \\
\hline Combined & 46 & 0.4650 & 0.0411 & 0.3107 & 0.0435 & -0.0004 & 27.3 & 1.20 \\
$1987-88$ & 24 & 0.4745 & 0.0301 & $0.5828^{* *}$ & $0.0209^{* *}$ & -0.0001 & 40.1 & 1.21 \\
$1988-89$ & 22 & 0.6283 & 0.0387 & $-0.2683^{* *}$ & $0.1019^{* *}$ & $-0.0013^{* *}$ & 19.0 & 1.18 \\
\hline
\end{tabular}

$\mathrm{b}_{0}{ }^{2}=$ intercept, $\mathrm{b}_{1}=$ slope herbage allowance, $\mathrm{b}_{2}=$ slope of herbage allowance ${ }^{2}$.

${ }_{3}^{2}$ Critical value refers to the level of herbage allowance that average daily gain plateaus.

Plateau refers to the vlaue of average daily gain attained at the critical point.

** The asymptotic $95 \%$ confidence intervals for bo, bl, and b2 do not overlap between years therefore differ. 
near average in amount and distribution in 1987-88 and dry and cold post-planting in 1988-89 (Fig. 1). Therefore, the relationship for combined years is more representative of median years than either individual year and accounted for $47 \%$ of the variation in ADG (Table 5). In contrast, Redmon et al. (1995) reported that herbage allowance of 1 cultivar during short-term grazing trials accounted for $59 \%$ of the variation in estimated ADG utilizing a nonlinear plateau model. These authors reported a critical value of $23 \mathrm{~kg} \mathrm{DM} 100 \mathrm{~kg} \mathrm{BW}^{-1}$ day $^{-1}$ compared to $27.3 \mathrm{~kg} \mathrm{DM} 100 \mathrm{~kg}$ $\mathrm{BW}^{-1}$ day $^{-1}$ in our study. The decreased predictive capability of our model would be expected because we encouraged greater range of environmental conditions and cattle and wheat developmental phases. Furthermore, 2 cultivars of contrasting forage production potential, growth habit and winter hardiness were included in the study. Reported differences in plateau ADG's of 1.3 to $1.2 \mathrm{~kg}$ between studies are minimal and may reflect environmental stress impacts on performance in our experiment. Late season relationships between herbage allowance and ADG may be complicated by the concurrent decline in forage nutritive value with advancing maturity of wheat.

\section{Literature Cited}

Anderson, M.A. and G.W. Horn. 1987. Effect of lasalocid on weight gain, ruminal fermentation and forage intake of stocker cattle grazing winter wheat pasture. J. Anim. Sci. 65:865-871.

Bartley, E.E., G.W. Barr, and R.M. Mickelsen. 1975. Bloat in cattle. XVII. Wheat pasture bloat and its prevention with proloxalene. J. Anim. Sci. 41:752-756.

Biondini, M.E., W.K. Lauenroth, and O.E. Sala. 1991. Correcting estimates of net primary production: Are we overestimating plant production in rangelands? J. Range Manage. 44:194-198.

Carver, B.F., E.G. Krenzer, Jr., and W.E. Whitmore. 1991. Seasonal forage production and regrowth of hard and soft red winter wheat. Agron. J. 83:533-537.

Christiansen, S., T. Svejcar, and W.A. Phillips. 1989. Spring and fall cattle grazing effects on components and total grain yield of winter wheat. Agron. J. 81:145-150.

Cravey, M.D., G.W. Horn, F.T. McCollum, P.A. Beck, and B.G. McDaniel. 1993. High-starch and high-fiber supplements improve performance of stocker cattle grazing wheat pasture, p. 262-268. In: Anim. Sci. Res. Rep., Oklahoma Agr. Exp. Sta. MP-933, Stillwater, Okla.

Defosse, G.E. and M.B. Bertiller. 1991. Comparison of four methods of grassland productivity assessment based on Festuca pallescens phytomass data. J. Range Manage. 44:199-203.

Dunphy, D.J., E.C. Holt, and M.E. McDaniel. 1984. Leaf area and dry matter accumulation of wheat following forage removal. Agron. J. $76: 871-874$

Harman, W.L., J. McNeil, and G.B. Thompson. 1984. Estimating costs and returns for wheat crop alternatives in the Southern Plains. pp. 377-396. In: G.W. Horn (ed.) Proc. of Nat. Wheat Pasture Symp. Oklahoma Agr. Exp. Sta., MP-115. Stillwater, Okla.

Horn, G.W. and D.F. Frost. 1982. Ruminal motility of stocker cattle grazed on winter wheat pasture. J. Anim. Sci. 55:976-981.

Horn, G.W., M.D. Cravey, F.T. McCollum, C.A. Stasia, E.G. Krenzer, Jr., and P.L. Claypool. 1995. Influence of high-starch versus high-fiber energy supplements on performance of stocker cattle grazing wheat pasture and subsequent feedlot performance. J. Anim. Sci. (In Press).

Horn, G.W., T.L. Mader, S.L. Armbruster and R.R. Frahm. 1981. Effect of monensin on ruminal fermentation, forage intake and weight gains of wheat pasture stocker cattle. J. Anim. Sci. 52:447-451.
Mader, T.L. and G.W. Horn. 1986. Low-quality roughages for steers grazing wheat pasture. II. Effect on wheat forage intake and utilization. J. Anim. Sci. 62:1113-1119.

Mader, T.L., G.W. Horn, W.A. Phillips, and R.W. McNew, 1983. Low quality roughages for steers grazing wheat pasture 1. Effect on weight gains and bloat. J. Anim. Sci. 56:1021-1028.

Redmon, L.R., F.T. McCollum, G.W. Horn, M.D. Cravey, S.A. Gunter, P.A. Beck, J.M. Mieres, and R.S. Julian. 1995. Forage intake of beef steers grazing winter wheat with varied herbage allowance. J. Range Manage. 48:198-201.

SAS, Institute, Inc. 1987. Sas/Stat ${ }^{\text {TM }}$ guide for personal computers. 6th ed. Statistical Anal. System Institute, Inc. Cary, N.C.

West, C.P., D.W. Walker, R.K. Bacon, D.E. Longer, and K.E. Turner. 1991. Phenological analysis of forage yield and quality in winter wheat. Agron. J. 83:217-224.

Winter, S.R. and J.T. Musick. 1991. Grazed wheat grain yield relationships. Agron. J. 83:130-135.

Winter, S.R. and E.K. Thompson. 1987. Grazing duration effects on wheat growth and grain yield. Agron. J. 79:110-114.

Winter, S.R. and E.K. Thompson. 1990. Grazing winter wheat: I. Response of semidwarf cultivars to grain and grazed production systems. Agron. J. 82:33-37.

Worrall, W.D. and E.C. Gilmore. 1985. Forage of small grains for the Rolling Plains. Texas Agr. Exp. Sta. MP-1584. College Station, Tex..

Zar, J.H. 1974. Biostatistical analysis. Prentice-Hall, Inc. Englewood Cliffs, N.J. 